\title{
RELATIONS BETWEEN COORDINATORS OF UNDERGRADUATE COURSES AND TECHNOLOGIES: INTERLACEMENTS IN DIGITAL CULTURE !?
}

\author{
Maria Cristina Lima Paniago, Rosimeire Martins Régis dos Santos and Arlinda Cantero Dorsa \\ Universidade Católica Dom Bosco (UCDB), Brazil
}

\begin{abstract}
The objective of this work is to understand the relations between university coordinators of undergraduate courses and technologies in digital culture. The context of the research is a private university, looking at seven coordinators of undergraduate courses and their relations with technologies in digital culture. It is part of a larger research project also involving teachers and students. At this time, focusing on the coordinators, we used online questionnaire available on google drive and interviews. The two instruments focused on: personal information; initial and ongoing training processes; teaching performance; relationships between teachers / coordinators / students / computers / internet; and, pedagogical appropriations. The produced data show the coordinators'awareness about the huge universe of information available by the digital context and about their challenge of gradually integrating more technologies into their management and also teaching activities. We emphasize that the coordinators pointed as important not only technical issues related to internet access as well as its speed, but also the necessity of different ways of appropriations of technologies looking at new and more qualitative proposals of management and teaching and learning. The research has revealed aspects that deserve expanding continuing education in order to create conditions among university coordinators, teachers and students for establishing dialogues and spaces about education with technologies, influenced by this new digital culture that reflects directly on different education in contemporary times.
\end{abstract}

\section{KEYWORDS}

Coordinators of Undergraduate Courses, Digital Culture, Technologies, Educator Training and Practice

\section{INTRODUCTION}

The present proposal arises in the context in which digital technologies are increasingly permeated, intertwined, inserted and sometimes interlaced in some way in our personal as well as social routines, including professional and educational ones.

In this sense, we understand that if digital technologies are embedded in our lives, it will be necessary to understand them so that we can benefit from their potentialities, adding them to the improvement of our lives.

It is a qualitative research, part of a larger research project involving teachers, students and coordinators. It happened in a private university and there was a combination of different generations of records: online questionnaires, digital narratives on Facebook and interviews. Focusing on the previous results available in other publications, there were 39 teachers and 285 students answering the questionnaires and 77 teachers participating in facebook. According to the data, the minority of the teachers respondents are in the young age group and the majority in the adult or old age group. However, this is not an impediment to changes and transformations, since the age group does not imply more or less critical appropriation of ICTs, but the creative will to produce differently. Also the data showed that the internet is present in the life of teachers and quite often. We might think that perhaps this is a possibility of innovation added to experiences already experienced.

About the students, the data showed an extreme relevance at investigating digital culture in a confessional Brazilian center-west Univesity, especially, because the research could identify the students'profiles, which technologies are part of their lives, their conceptions about the Technologies and digital culture, besides understanding which technologies are used and involved at their education processes. Looking at those partial results, they make us thinking about new questions relating to digital culture, such as how we could promote the ciberculture at the spaces of university. 
The last participants of the research, focus at this article, are the coordinators. We therefore seek to understand the relations between undergraduate course coordinators and technologies, immersed or not in a context of digital culture. The exclamation and questioning marks in the title refer respectively to how good that the coordinators are inserted in a context of digital culture and at the same time to the doubt if they really are taking advantage of the digital culture.

Although the digital culture is announced or it is very well publicized, it is important to problematize it. We could start with the question to whom the digital culture exists, is it guaranteed for all the people? Next, we could also ask about how digital culture is developed and subsidized. There are some constituent elements that for us, educators, are essential in the practices of teaching and learning with technologies, such as technological and pedagogical subsidies, focusing at teacher training, working conditions, educational policies, contemporary curriculum, dialogic, participatory and collaborative educational perspectives.

To understand if such digital culture happens and how/why it occurs could help us think about different ways of educating, according to the contemporaneity. Perhaps this is a differentiated path in educational processes in which we can break the hierarchy, the domination of those who call themselves those who know about those who do not know, the breakdown of the hegemony of some knowledge to the detriment of others, and the (re) construction of a more democratic, less monological, more collaborative and reflective teaching practices.

\section{CONTEXT OF THE RESEARCH AND ITS PARTICIPANTS}

For the purposes of analysis, the qualitative approach was used, which provides a closer relationship between the researcher and the information bases. According to Richardson (2008, p. 79), the qualitative approach to a problem, besides being an option of the researcher, is justified, above all, because it is an adequate way to understand the nature of a social phenomenon. And he adds that the qualitative method differs in principle from the quantitative one as it does not employ statistical tools as the basis of the process of analyzing a problem.

We use a questionnaire, according to Triviños, the questionnaire with open questions can become an important vehicle to achieve the objectives that the qualitative researcher proposes when developing a research, and it is perhaps one of the most decisive instruments to study the processes and products in the which the qualitative researcher is interested (Triviños, 1987, p.138).

To enrich the data from the questionnaire, we opted for semistructured interviews by combining closed and open questions, in which the interviewee has the possibility to discuss the subject in question without being bound by the inquiry formulated (Minayo, 2012, p. 64). Minayo (2012) understands that when entering the field, the interviewer should take into account some practical considerations. He/she must introduce; himself/herself; briefly discuss the work for the interviewee; present the institutional credential; explain the reasons for the research; justify the interviewee's choice; guarantee the anonymity and confidentiality of data; have an initial conversation in order to break the ice, to see if the possible interviewee is willing to give information and create a relaxed atmosphere as much as possible (Minayo, 2012, p. 67).

The research was carried out in a private, confessional university, located in the center-west of Brazil, whose physical structure is modern and it has in its campus library, Clinic School, Veterinary Hospital, Laboratories, Nucleus of Juridical Practices, Vivarium School, Gymnasium, among others, offering subsidies for the teaching and learning process in different undergraduate, graduate and extension courses. We remind that the research was approved by the research ethics committee and it maintains the anonymity of its participants.

Seven coordinators of undergraduate courses participated in the research, entitled Coordinator A, B, C, D, E, F, G. They answered a google drive questionnaire. Google drive is a Google application that makes it possible to generate records and interviews by whatsapp application, concerning personal information, education, training and professional performance, including teacher activities, and the relationships between teachers / students / coordinators / computers / internet and their uses. It should be remembered that some coordinators are also teachers. 
About the profiles of the 07 coordinators, most of them are between 31 and 45 years old. According to Souza (2013, p. 17), the concept of a native and digital immigrant, idealized by Marc Prensky in his work 'Nativos Digitais, Imigrantes Digitais' (Digital Natives, Digital Immigrants) published in 2001, was trivialized and reduced to a question of age group. For Souza (2013, p.17), what is perceived is that they idealized the Natives as individuals born after 1980 and Digital Immigrants as born before this date. According to the author (2013, p.17), it is believed that Digital Immigrants can assume characteristics such as 'Network Experience', 'Experience / maturity' and 'navigability / connectivity' not having difficulty in the experiences and experiences that they assume in the cyberspace.

We believe, as Souza (2013), that the problem goes beyond the issue of age and it deepens the question of appropriation of information and communication technologies (ICT) in a creative, collaborative, critical and ubiquitous way in the production of different cultures, knowledge.

\section{DIGITAL CULTURE AND ITS MANIFESTATIONS: SOME INTER-RELATIONS}

This construction of the so-called digital culture manifests itself in the forms of communication and relations in the use of the new technologies that present themselves with two important characteristics: direct relation with the contemporary world and constant changes from the use of technological tools.

Digital culture, also called as cyberculture, presents different nomenclatures and meanings. Lemos (2002) points out some problems related to the many definitions of cyberculture. According to the author, besides the term getting different meanings, it uses the prefix cyber, which may denote a certain technological determinism, habit of naming the historical epochs from their respective artifacts. On the other hand, we can also live a social determinism, when, for example, we live the contemporary culture marked by digital technologies, such as in banking transactions, electronic voting and others. The important thing is to escape such determinisms and to understand that cyberculture (Lemos, 2002) represents contemporary culture and it is a direct consequence of the evolution of modern technical culture.

Scholars such as Castells (1999) emphasize interconnection, access and mediation through digital networks as the process of communication and global connectivity permeated by digital culture.

In this sense, some coordinators pointed out as necessary, greater access to the internet and also their speed, to optimize the process of teaching and learning. In addition, they also scored technical questions, that is, the need to keep computers always working well and fast. In addition to this, Cazeloto (2009), Lemos (2009) and Lessig (2008) affirm that the provoked change goes beyond the so-called technicalism because it involves not only dialectical and dialectical relations but also artistic and identity manifestations, as well as principles of collaboration, of horizontality, of decentralization in public-private-social relations.

According to Coordinator A, digital culture is almost everywhere and it is part of our routines. He pointed out that digital culture is this "new world" of information around us, as the financial system, communication (telephone replaced by WhatsApp), by email (digitilized documents and large storage capacity, and education (it can permeate the Distance Education) but inside the classrooms it is already remarkable this digital culture. He also said that for the area he works in (architecture and urbanism) it is already part of daily life, so that most of the people involved, they already work with digital culture, mainly outside the country.

It is important to reflect that digital technologies are embedded and integrated into the social area, changing lifestyles, various business models, education, social and family relationships, various forms of entertainment through social networks as Youtube, Facebook, Instagram and twitter, whether through smartphone applications, tablets. This is a moment in history when digital technologies can no longer be analyzed only as tools, but as active participants in our culture. (Bortolazzo, 2016, p.146).

According to the Coordinator E, she thinks we are weaving and communicating to each other in a very fast way. In addition to it, she states we are also able to be more co- operative and informative. For her, connectivity is in the first place in everything we do and talk about.

To Know what we do with digital social networks is not as important as to know what the networks are doing to us, in relation to our subjectivity and sociability, our memory, our expectations, our yearnings and our desires. Another relevant aspect is to know what they are doing with our ways of receiving information, of becoming aware of the facts, of acquiring knowledge, of perceiving and representing the world, what they are doing with our learning processes and, possibly, with our ways of teaching and educating (Santaella, 2013). 
These concerns appear in the statements of the majority of the coordinators, focusing on improving the appropriation of technologies as well as their use in the learning process.

In addition to promoting circulation, social media opens space for the creation of environments of instant coexistence between people. They thus instal a participatory culture, in which each one counts and all collaborate, therefore, an integrative culture, assimilative, a culture of coexistence that evolves according to the requirements imposed by the participants' use. It is a culture in which its members believe that their contributions matter and develop a certain degree of social connection with the other, so that what others think or what they are supposed to think about what each one creates, however insignificant they are. (Santaella, 2013, pp. 44-45).

For Coordinator B, the way we act today, at work, with family, our relations in different areas, today is no longer analogical, it is digital. It passes through components such as computers, tablets, mobiles, tools, applications, then all the technologies that are in computing environment, they are in digital form, not analogical. So, before we sent a written letter, telegram and today we communicate by whatsapp and in different ways. All this shows changes, changes in our ways of communicating, of relating ourselves to our ways of living.

Facing these changes, the digital culture seems to make us dare to (re) invent other ways to educate others and also educate ourselves corroborating what the majority of the coordinators understand. They agree with the need to seek new methods of teaching and learning through the use of technology in order to improve teaching and also professional activities.

In this context, it is important to reflect about how important and necessary it is to be able to listen. Freire extends this reflection by stating that as a democratic relationship, dialogue is the possibility that he has of being open to think of others, not fading in isolation (Freire, 2006b, p. 120). For him, it is important to know the existing knowledge, and to know that we are open and able to produce knowledge that does not yet exist (Freire, 1996, p.31).

In this sense, it is important to emphasize Kenski's thought (1998, pp. 69-70) about the teacher should have time and opportunities of familiarization with the new educational technologies, including their possibilities and limits. In this way, he/she could in practice make conscious choices about the use of the most appropriate forms of teaching.

Kenski (1998, p.70) points out that the didactic difference is not at the use or non-use of new technologies, but at the understanding of their possibilities and at the understanding of the logic that permeates the movement between the knowledge in the present stage of technological society.

We understand that digital culture can provide other ways to build knowledge, streamlining the educational process. When it comes to Information and Communication Technologies, we need to incorporate them in a meaningful and critical way and we appropriate them to optimize and qualify our ways of teaching and learning. Moreover, viewing digital culture as a possibility to implement exchanges, including international and intercultural exchanges of knowledge, can enrich and give opportunities for other interlacings.

\section{FINAL CONSIDERATIONS}

The present research between technologies and education, with regard to the digital culture of coordinators from undergraduate courses, proposes reflections that lead us to think about taking advantage of other ways to communicate and to acquire knowledge. Therefore, considering digital culture at the educational context can be another perspective of stimulating and promoting different dialogues, problematizations, questionings and (re) constructions of other ways of qualitative and colaborative living. Looking at what and how teachers, students, coordinators think, conceive and relate digital culture at the educational environment can help us developing learning and teaching communities, which can also improve our own world. 


\section{REFERENCES}

Bortolazzo, Sandro Faccin. (2016). O imperativo da cultura digital: entre novas tecnologias e estudos culturais (The imperative of digital culture: between new technologies and cultural studies). Rev. Cad.Comun, Santa Maria, v.20, n.1, art 1, p.1 de 24, jan/abr.

Castells, M. (1999). A sociedade em rede. São Paulo: Paz e Terra.

Cazeloto, E. (2009). Apontamentos sobre a noção de "democratização da internet". In: Trivinho, E., Cazeloto, E. A cibercultura e seu espelho: campo de conhecimento emergente e nova vivência humana na era da imersão interativa. São Paulo: ABCiber; Instituto Itaú Cultural.

Freire, Paulo. (1996). Pedagogia da autonomia: Saberes necessários à prática educativa (Pedagogy of Autonomy). (25a ed). São Paulo: Paz e Terra

Freire, Paulo.(2006b). Pedagogia da esperança: um reencontro com a pedagogia do oprimido (Pedagogy of Hope). Rio de Janeiro: Editora Paz e Terra.

Kenski, V. M. (1998). Novas tecnologias. O redimensionamento do espaço e do tempo e os impactos no trabalho docente (New Technologies. The resizing of space and time and the impacts on teaching work). Revista Brasileira de Educação, São Paulo, n. 8, p. 58-71, jul./ago.

Lemos, André. (2002). Cibercultura: Tecnologia e Vida Social Contemporânea. Porto Alegre: Editora Sulina.

Lemos, André. (2009). A cibercultura como território recombinante. In: Trivinho E, Cazeloto E (org.). A cibercultura e seu espelho: campo de conhecimento emergente e nova vivência humana na era da imersão interativa. São Paulo: ABCiber.

Lessig, L. (2008). Remix: making art and commerce thrive in the hybrid economy. New York: The Penguin Press, Penguin Group.

Minayo, M. C. S. (2012). Pesquisa Social: Teoria, método e criatividade (Social Research: Theory, method and creativity). Petrópolis: Vozes, (32a ed).

Richardson, R.J. (2008). Pesquisa social: métodos e técnicas (Social research: methods and techniques). 3a. ed. São Paulo: Atlas.

Santaella, Lucia. (2013). Intersubjetividade nas redes digitais: repercussões na educação. In: Primo, Alex (Org.). Interações em Rede (Network Interactions). Coleção Cibercultura. Porto Alegre: Editora Sulina.

Souza, M. de. (2013). O real conceito de nativos e imigrantes digitais nas redes sociais digitais: conceitos, vivências e comportamento (The real concept of digital native and immigrants in digital social networks: concepts, livings and behaviours). Dissertação de Mestrado em Cognição e Linguagem. Universidade Estadual do Norte Fluminense Darcy Ribeiro, Centro de Ciências do Homem.

Triviños, A. N. S. (1987). Introdução à pesquisa em ciências sociais: a pesquisa qualitativa em educação (Introduction to research in social sciences: the qualitative research in education). São Paulo: Atlas, 1987. 